10IKC-179

\title{
MINERAL CHEMISTRY OF THE PERIDOTITES FROM THE NAGA OPHIOLITE BELT, NORTHEASTERN INDIA AND THEIR PETROLOGICAL SIGNIFICANCE
}

\author{
B. Maibam \\ Department of Earth Sciences, Manipur University, Imphal-795003, INDIA
}

The ophiolite belt of northeastern India is regarded as the continental extension of the Indonesia island arc evolved as a result of obduction of the Indian and Burmese plates. The ophiolite sequence forms a belt extending about $200 \mathrm{~km}$ from Pukhpur (Nagaland state) in the north to Moreh (Manipur state) in the south. The rootless allocthonous ophiolitic belt consists of different igneous, metamorphic and sedimentary sequences. Ultramafic rocks forming the main component of the belt are consists of mantle sequence of tectonised peridotites with mafic intrusives, volcanic rocks, pelagic sediments (Bhattacharjee, 1991). Some mantle derived xenoliths are also reported from the belt. In general, localized along the suture zones, ophiolites and associated ophiolitic mélanges witness the closure of an oceanic domain during continent-continent convergence. The northeastern India ophiolite provides a good opportunity for the comprehensive study of fragments of oceanic lithosphere, especially its mantle section.

Mineral compositions of the peridotites representing the mantle section of the ophiolite and mantle derived peridotite xenoliths collected from the northern part of the belt in the Nagaland sector are presented here and use the result to recognize the probable crystallization setting of the studied samples. The two peridotite varieties may provide an excellent opportunity to understand processes of heterogeneous mantle melting. The purpose of the present study is to: (i) estimate the equilibrium condition of the two type of peridotite and (ii) understand the nature of the lithospheric mantle beneath the region.

\section{PETROGRAPHICAL STUDY}

Most of the peridotite associated with the ophiolite samples have been altered and overprinted by growth of serpentine minerals to varying degrees, which obscures the primary textures as olivine grains are divided into numerous small relict grains separated by serpentine mesh texture. In extreme cases, orthopyroxene may be replaced by serpentine to form the psuedomorph bastite. Spinel and clinopyroxene are generally unaltered; however, chromite may have rims of magnetite or ferrichromite. Unaltered relicts of olivine and pyroxene as cumulus phases are also present. Some of the samples show exsolved lamellae of orthopyroxene. Photomicrograph of peridotite representing the mantle sequence of the ophiolite representing the unaltered relict phases and backscattered electron images of clinopyroxene lamellae in orthopyroxene grain are presented in Figs. 1 and 2 respectively. Serpentinite is fibrous in nature and occurs radially around the unaltered relicts of pyroxene and olivine. Dolomite and magnesite are present as veins in the serpentinites and talc occurs as fracture fillings. 


\section{0 $^{\text {th }}$ International Kimberlite Conference, Bangalore - 2012}

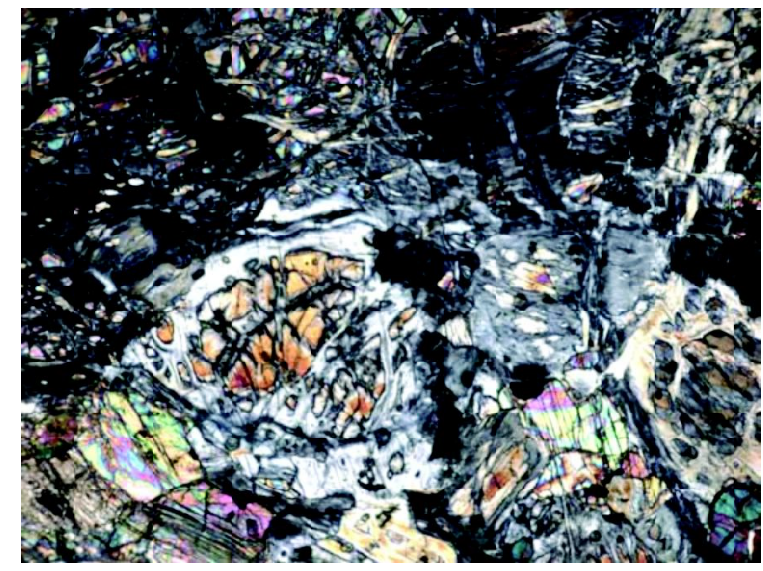

Fig. 1. Photomicrograph of partially altered peridotite representing the mantle section of the ophiolite.

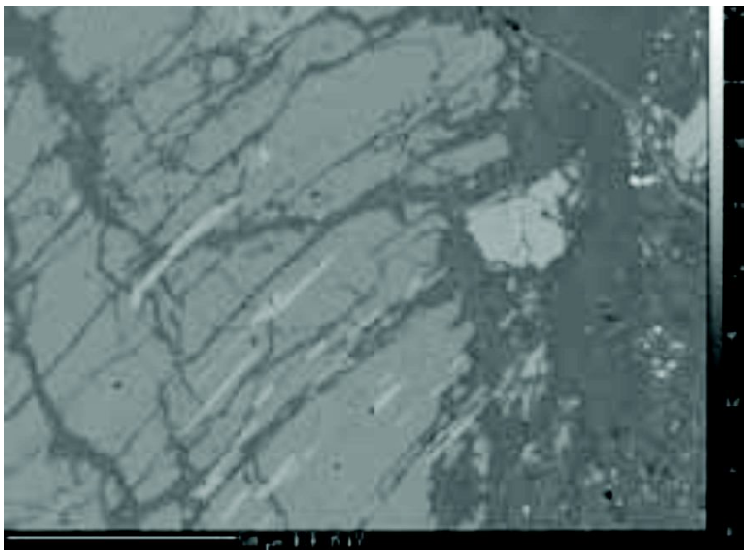

Fig. 2. Backscattered electron image orthopyroxene hosting the clinopyroxene lamellae.

The xenolith peridotite samples are relatively fresher and almost unaltered. The grain size is smaller than the studied ultramafic rocks associated with the ophiolite sequence. Olivine grains do not show any strain effects (e.g., undulose extinction, deformation bands etc.) and individual grains are optically very homogenous. Orthopyroxenes occasionally exhibit deformation twins and exsolution lamellae of clinopyroxenes. Clinopyroxene porphyroclasts are rare and sometimes show exsolution lamellae of orthopyroxene. Grain boundaries of porphyroclasts are irregular, strongly lobated.

\section{MINERAL CHEMISTRY OF THE PHASES}

The chemical composition of olivine in the xenolith ranges from $\mathrm{Fo}_{80}$ to $\mathrm{Fo}_{87}$. $\mathrm{MnO}$ contents of analyzed olivine ranges from 0.14 to $0.22 \mathrm{wt} \%$, and $\mathrm{CaO}$ varies from 0.20 to $0.26 \mathrm{wt} \%$. Analyzed olivine is devoid of $\mathrm{Cr}_{2} \mathrm{O}_{3}$ and $\mathrm{NiO}$.

The ultramafic sequence of the ophiolite samples shows extensive alteration to serpentine. In most cases remnants of olivine occur as relicts in the serpentine matrix. Olivine of the ophiolite mantle sequence ultramafic contain $\mathrm{NiO} 0.27-$ 0.54 wt. \%, $\mathrm{Cr}_{2} \mathrm{O}_{3} 0.01-0.33, \mathrm{CaO} 0.01-0.06, \mathrm{TiO}_{2}$ 0.01-0.04, however the trace element like $\mathrm{Cr}, \mathrm{Ca}$ and $\mathrm{Ti}$ in some olivine are below the detection limit. Olivine associated with the mantle sequence ultramafite of the ophiolite shows higher $\mathrm{Fo}_{89}$ to $\mathrm{Fo}_{91}$.

Xenolith orthopyroxenes are magnesium rich compositions $\left(\mathrm{En}_{92-95}\right)$ with trace amounts of $\mathrm{CaO}\left(0.30-0.58\right.$ wt.\%), and variable $\mathrm{Al}_{2} \mathrm{O}_{3}$ between 0.61-1.02 wt.\%. The analysed orthopyroxene have variable $\mathrm{Cr}_{2} \mathrm{O}_{3}$ between 0.34 0.83 wt. $\%$. The ophiolite orthopyroxene could make out from the xenolith ones from their higher $\mathrm{CaO}$ between 0.32 to 1.74 wt. $\%, \mathrm{Al}_{2} \mathrm{O}_{3} 1.23$ to 2.55 wt. $\%$ and $\mathrm{Cr}_{2} \mathrm{O}_{3} 0.30$ to 1.10 wt. $\%$.

Xenolith clinopyroxenes have high $\mathrm{Cr}$ contents $\left(0.40-0.60\right.$ wt. $\left.\% \mathrm{Cr}_{2} \mathrm{O}_{3}\right)$ and $\mathrm{Na}_{2} \mathrm{O}$ ranging between 0.12 to 0.17 wt. $\%$ and the samples are slightly titaniferous with $\mathrm{TiO}_{2}$ varying between 0.11 to 0.17 . Ophiolite clinopyroxene is chromian diopside with $\mathrm{Cr}_{2} \mathrm{O}_{3}$ ranging between 0.64 to $1.02 \mathrm{wt} \%$, higher $\mathrm{Na}_{2} \mathrm{O} 0.30-1.10$ and $\mathrm{TiO}_{2}$ 0.20 to 0.34 than xenolith clinopyroxene.

Spinel from the peridotites show low and variable $\mathrm{Cr}$ number $(\mathrm{Cr} /(\mathrm{Cr}+\mathrm{A} 1) 0.09$ to 0.29$)$ and the $\mathrm{Mg}$ number ranges between 0.67 to 0.78 and corresponding values for the $\mathrm{Cr}$-spinels ranges from 0.60 to 0.70 and 0.66 to 0.70 respectively. Phase chemistry indicates that the spinels associated with the ultramafic rocks are abyssal variety. 
Spinels are Al-rich and plot at the low $\mathrm{Cr}$ no. of the abyssal peridotite spinel array (Fig. 3). The studied pyroxenes also plot in compositional fields of abyssal peridotites in minor element versus Mg no. plots (Fig. 4).

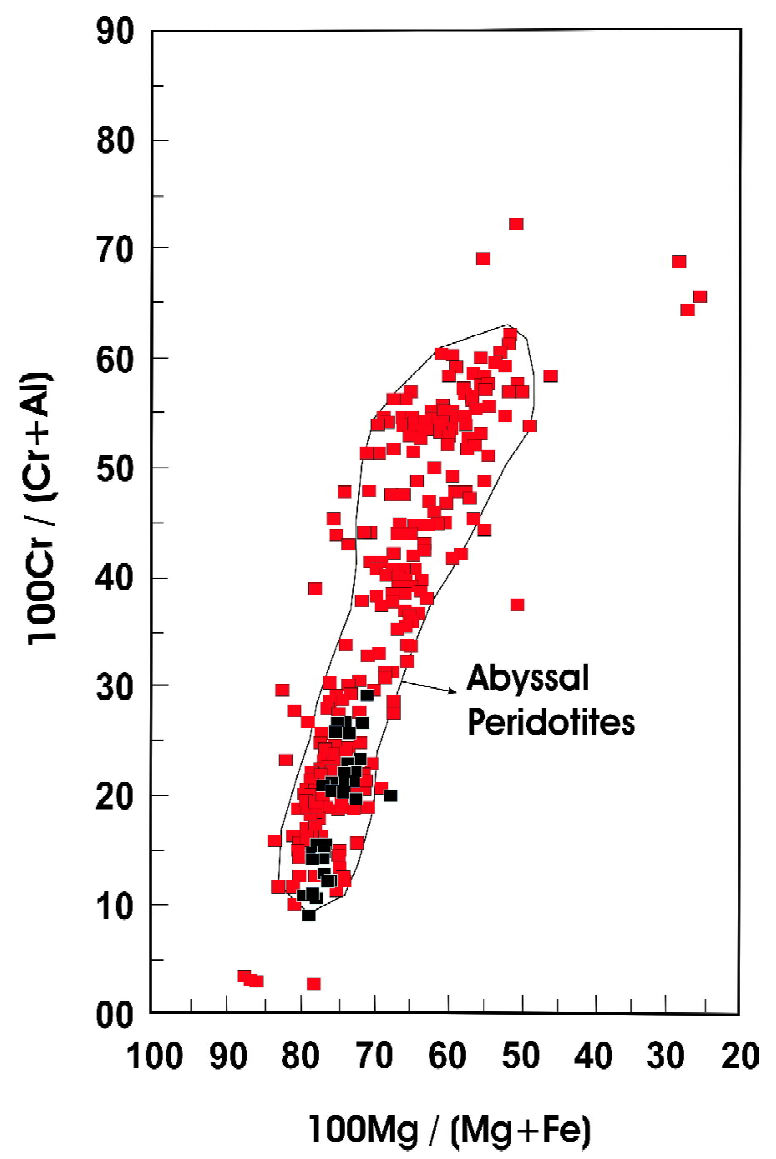

Fig. 3. Plot of $100 \mathrm{Cr} /(\mathrm{Cr}+\mathrm{Al})$ vs. $100 \mathrm{Mg} /(\mathrm{Mg}+\mathrm{Fe})$ of spinels

\section{EQUILIBRIUM CONDITIONS}

Equilibrium pressure and temperature conditions were calculated using the various standard geothermobarometer. Based on the Wells's (1977) single clinopyroxene geothermometry, equilibrium temperature of the studied peridotites found to cover a wide range (780-1250 $\left.{ }^{\circ} \mathrm{C}\right)$, the lower temperature indicating possible post crystallization re-equilibration of some of the samples. Pressure was calculated

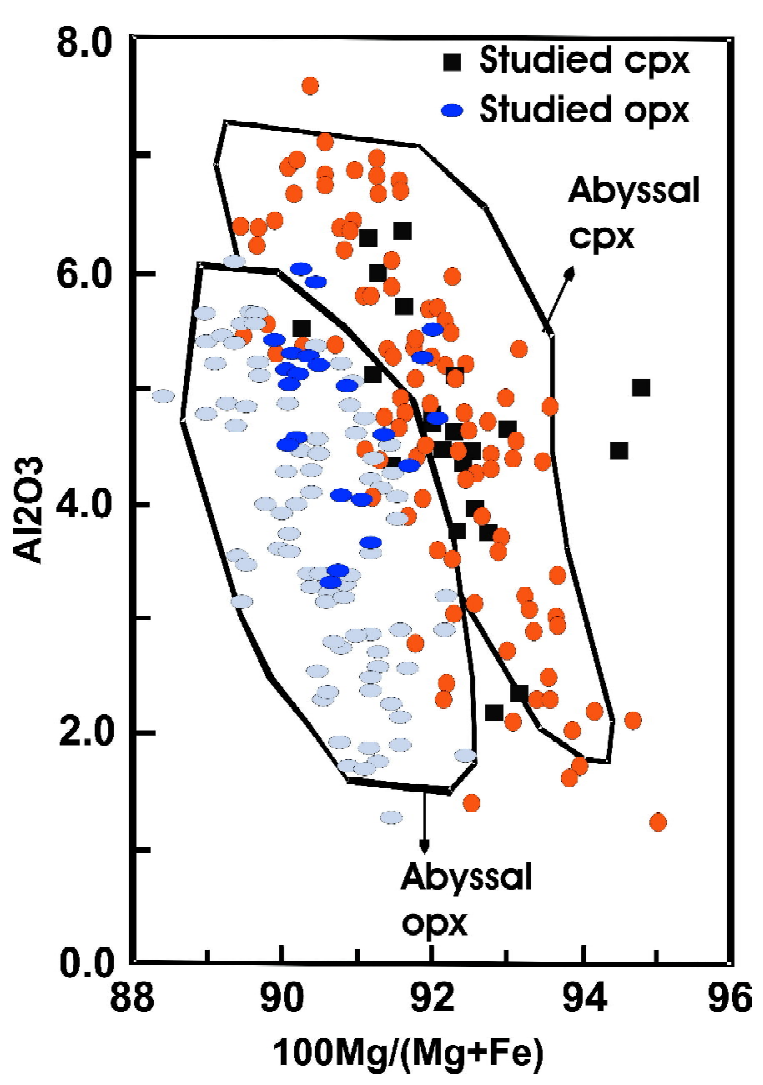

Fig. 4. Plot of $\mathrm{Al}_{2} \mathrm{O}_{3}$ vs. $100 \mathrm{Mg} /(\mathrm{Mg}+\mathrm{Fe})$ of proxenes

using Nimis and Ulmer's single clinopyroxene (1998) and Köhler and Brey's (1990) olivinespinel geobarometries the equilibrium pressure is calculated between 19 to $25 \mathrm{kbar}$. Oxygen fugacity was calculated using Ballhaus's et al. (1991) equation and expressed in terms of quartz-fayalitemagnetite (DQFM) buffer value ranges from -1.32 to -3.46 .

Peridotites associated with oceanic crust provide important information on the process of melt generation, fluid phase enrichment, and mantle-melt interactions subsequent to melt extraction (e.g., Choi et al., 2008, Dick 1989; Johnson et al. 1990; Seyler et al. 2001, 2007; Hellebrand et al. 2002). Many earlier workers (Dick and Bullen 1984; Dick and Fisher 1984; Dick 1989; Johnson et al. 1990; Johnson and Dick 1992) have shown that abyssal peridotites 


\section{0 $^{\text {th }}$ International Kimberlite Conference, Bangalore - 2012}

represent the residues of fractional melt extraction to form MORB. Using the Cr no. of the spinel, the ophiolite peridotites are found to moderately partially melted (5-11\% partial melting).

\section{References}

Ballhaus, C., Berry, R.F., Green D.H. (1991) High pressure experimental calibration of the olivineorthopyroxene-spinel oxygen barometer: implications for the oxidation state for the upper mantle. Contrib. Mineral. Petrol. 107, 27-40.

Bhattacharjee, C.C. (1991) The ophiolites of northeast India - a subduction zone ophiolite complex of the Indo-Burman orogenic belt. Tectonophys., 191, (1991) 213-222.

Choi, S.H., Shervais, J.W., Mukasa, S.B. (2008) Suprasubduction and abyssal mantle peridotites of the Coast Range ophiolite, California. Contrib. Mineral. Petrol., DOI 10.1007/s 00410-0080300-6.

Dick H.J.B. (1989) Abyssal peridotites, very slow spreading ridges, and ocean ridge magmatism. In: Saunders A.J., Norry M.J. (eds) Magmatism in the Oceanic Basins. Geol Soc London Spec Publ., 42, 71-105.

Dick H.J.B., Bullen T. (1984) Chromian spinal as a petrogenetic indicator in abyssal and alpine-type peridotites and spatially associated lavas. Contrib. Mineral. Petrol., 86, 54-76.

Dick H.J.B., Fisher R.L., Bryan W.B. (1984) Mineralogic variability of the uppermost mantle along mid-ocean ridges. Earth. Planet. Sci. Lett., 69, 88-106.
Johnson K.T.M., Dick, H.J.B. (1992) Open system melting and temporal and spatial variation of peridotite and basalt at the Atlantis II fracture zone. J. Geophys. Res., 97, 9219-9241.

Johnson K.T.M., Dick H.J.B., Shimizu N. (1990) Melting in the oceanic upper mantle; an ion microprobe study of diopsides in abyssal peridotites. J. Geophys. Res., 95, 2661-2678.

Hellebrand E., Snow J.E., Hoppe P., Hofmann A.W. (2002) Garnet field melting and late stage refertilization in residual abyssal peridotites from the Central Indian ridge. J. Petrol., 43, 2305-2338.

Köhler T., Brey G.P. (1990) Calcium exchange between olivine and clinopyroxene calibrated as a geothermobarometer for natural peridotites from 2 to $60 \mathrm{~kb}$ with applications. Geochim. Cosmochim. Acta, 54, 2375-2388.

Nimis P., Ulmer P. (1998) Clinopyroxene geobarometry of magmatic rocks. 1. An expanded structural geobarometer for anhydrous and hydrous, basic and ultrabasic systems. Contrib. Mineral. Petrol., 133, 314-327.

Seyler M., Toplis M.J., Lorand J.P., Luguet A., Cannat M. (2001) Clinopyroxene microtextures reveal incompletely extracted melt in abyssal peridotites. Geology, 29, 155-158.

Seyler M., Lorand J.P., Dick H.J.B., Drouin M. (2007) Pervasive melt percolation reactions in ultradepleted refractory harzburgites at the Mid-Atlantic Ridge, 15-20 N: ODP Hole 1274A. Contrib. Mineral. Petrol., 153, 303-319.

Wells P.R.A. (1977) Pyroxene thermometry in simple and complex systems. Contrib. Mineral. Petrol., 62, 129-139. 